Sains Malaysiana 47(3)(2018): 537-542

http://dx.doi.org/10.17576/jsm-2018-4703-14

\title{
Salicylic Acid in Nutrient Solution Influence the Fruit Quality and Shelf Life of Cherry Tomato Grown in Hydroponics
}

(Asid Salisilik dalam Larutan Nutrien Mempengaruhi Kualiti Buah dan Jangka Hayat Tomato Ceri Hidroponik)

\author{
Mohammad Zahirul Islam, Mahmuda AKTer Mele, Ki-Young ChOI, Jun Pill BaeK \& Ho-Min Kang*
}

\begin{abstract}
Salicylic acid (SA) is a plant hormone that has functional effects in plant. This study was conducted to find out the effects of salicylic acid (SA) on cherry tomato fruit quality and shelf life. Different concentrations $(0.13,0.25,0.50$ and 1.00 $m M) S A$ were added in nutrient solution of hydroponic system in plants vegetation and fruits development stage. Lightred maturity stage of cherry tomato fruits was harvested to measure the harvest time fruit quality and stored at $5^{\circ} \mathrm{C}$ to measure the postharvest quality and shelf life. Ethylene production and respiration rate of tomato fruit at the harvest time and after storage was effectively reduced by the $0.50 \mathrm{mM}$ SA treatment. Increased acetaldehyde $(\mathrm{p} \leq 0.05)$ as well as ethanol $(\mathrm{p} \leq 0.001)$ was performed in the $0.50 \mathrm{mM} \mathrm{SA}$ treatment at after storage. The $0.50 \mathrm{mM} \mathrm{SA}$ treatment showed the lowest fresh weight loss $3.08 \%$ and the longest shelf life 25 days by reducing decay, fruits softening and fungal infection. Significantly lower fungal incidence $(\mathrm{p} \leq 0.001)$ was observed in the $0.50 \mathrm{mM}$ SA treatment. Final storage day color development and lycopene content was lower in the $0.50 \mathrm{mM}$ SA treatment compare with other treatments. The 0.50 mM SA treatment obtained the highest firmness at harvest time and it retain after storage. Comparatively higher vitamin $C$ and lower soluble solids was showed at the harvest time and after storage. Therefore, the $0.50 \mathrm{mM}$ SA treatment is effective in increasing the quality and shelf life of cherry tomato fruit.
\end{abstract}

Keywords: Ethylene production; firmness; respiration rate; soluble solids; vitamin C

ABSTRAK

Asid salisilik (SA) merupakan hormon tumbuhan yang mempunyai kesan kefungsian pada tumbuhan. Kajian ini dijalankan untuk mengetahui kesan asid salisilik (SA) terhadap kualiti dan hayat simpanan buah tomato ceri. Kepekatan SA yang berbeza telah ditambahkan dalam larutan nutrien sistem hidroponik dalam peringkat pertumbuhan pokok dan buahbuahan. Buah tomato ceri dituai pada peringkat kematangan merah bercahaya untuk mengukur waktu tuaian buah berkualiti dan disimpan pada $5^{\circ} \mathrm{C}$ untuk mengukur kualiti selepas tuaian dan hayat simpanan. Pengeluaran etilena dan kadar pernafasan buah tomato pada waktu tuaian dan selepas penyimpanan dikurangkan oleh $0.50 \mathrm{mM} S \mathrm{SA}$ dengan berkesan. Peningkatan asetaldehid ( $\mathrm{p} \leq 0.05)$ serta etanol $(\mathrm{p} \leq 0.001)$ telah dilakukan dalam rawatan 0.50 mM SA selepas penyimpanan. Rawatan $0.50 \mathrm{mM}$ SA menunjukkan penurunan berat segar terendah sebanyak $3.08 \%$ dan jangka hayat terpanjang selama 25 hari dengan mengurangkan pereputan, pelembutan buah-buahan dan jangkitan kulat. Pertumbuhan kulat yang lebih rendah $(\mathrm{p} \leq 0.001)$ diperhatikan dalam rawatan $0.50 \mathrm{mM}$ SA. Pertumbuhan warna penyimpanan hari terakhir dan kandungan lycopene lebih rendah dalam rawatan $0.50 \mathrm{mM}$ SA berbanding dengan rawatan lain. Rawatan 0.50 mM SA memperoleh ketegaran tertinggi pada masa tuaian dan bertahan selepas penyimpanan. Vitamin $C$ yang lebih tinggi dan pepejal larut rendah ditunjukkan pada masa penuaian dan selepas penyimpanan. Oleh itu, rawatan 0.50 mM SA berkesan untuk meningkatkan kualiti dan jangka hayat buah tomato ceri.

Kata kunci: Kadar pernafasan: ketegaran; penghasilan etilena; pepejal larut; vitamin C

\section{INTRODUCTION}

Salicylic acid (SA) is a natural and safe chemical to maintain postharvest quality of horticultural crops and nowadays its application is adopting, although chemical treatments are banning in many countries (Supapvanich \& Promyou 2013). SA is an active element of aspirin, and it regulates a number of processes in plants (Kumar et al. 2013) and mediate the defense in plant against pathogen (Javanmardi \& Akbari 2016).

In tomato, the SA influenced the defense pathway which induces resistance to $B$. cinerea but not to $O$. neolycopersici and in tobacco SA defense pathway induces resistance to $O$. neolycopersici but not to $B$. cinerea (Achuo et al. 2004). SA concentration, light, temperature, plant growing stages and plant species influenced the action on plants (Janda et al. 2014; Javanmardi \& Akbari 2016). SA delayed fungal incidence, prolonged the storage life and maintained the valuable attributes of postharvest tomatoes by inhibiting the ripening and senescence processes (Pila et al. 2010). Moreover, SA delayed the apple fruit ripening processes during postharvest storage (Mo et al. 2008). SA treatments were generally effective on vegetative growth, 
photosynthetic pigments, minerals, yield and tomato fruit quality (Kazemi 2014). SA inhibit grey mould growth, significantly decrease weight loss, increase storage life, maintain total soluble solids, titratable acidity, antioxidant, ascorbic acid and $\mathrm{pH}$ value in Kiwi fruits (Fatemi et al. 2013).

The exogenous application of SA influenced the secondary metabolites pathway through the plastids to represent the stress condition which modify the essential oil content (Rowshan \& Bahmanzadegan 2013). Foliar SA application increase plant growth, chlorophyll content in leaves, early yield and total yield and soluble solids, although it had no effect on $\mathrm{pH}$, ascorbic acid and titratable acidity of tomato (Yildirim \& Dursun 2009). The SA supply to the root system much increased the endogenous SA content of hydroponically grown tomato leaves (Spletzer \& Enyedi 1999) and SA levels also declined after $24 \mathrm{~h}$ of feeding hydroponically grown tobacco (Enyedi et al. 1992).

Most of researchers have focused foliar and postharvest SA application on different fruits and vegetables quality. Moreover, there was no previous study directly comparing the effects of SA treatments in nutrient solution on cherry tomatoes with respect to quality and shelf life. It is important to evaluate the effect of SA on quality and shelf life of cherry tomato fruit in nutrient solution. Therefore, in this study SA performance in nutrient solution was evaluated on quality and shelf life of cherry tomato fruit.

\section{MATERIALS AND METHODS}

Cherry tomato (Solanum lycopersicum cv. 'Unicorn') was cultivated at a plastic house through hydroponic system during April to July in Korea. 2.3dS• $\mathrm{m}^{-1}$ EC and 5.8-6.2 $\mathrm{pH}$ were maintained in given nutrient solution (Sato et al. 2006). The treatments were distilled water (control) and SA (Acetylsalicylic acid (Aspirin), Sigma Aldrich, USA) in four concentrations of $1.00,0.50,0.25$ and $0.13 \mathrm{mM}$ that were applied to the nutrient solution (Spletzer \& Enyedi 1999). As SA accumulation rates decrease due to increase in tomato plants age (Rahmawati et al. 2014), therefore, we treated SA in plant vegetation and development stage of fruit. Harvest time fruits quality and physiology parameters were measure at $20^{\circ} \mathrm{C}$ from light red maturitystage cherry tomato. In addition, same maturity fruits were stored at $5^{\circ} \mathrm{C}$ temperature of $85 \%$ relative humidity by cartons (commercial size) (Islam et al. 2013) to quantify postharvest quality and storability.

A 9900 PBI Dansensor (Check Mate, Denmark) acted to monitor the respiration rate. Ethylene, acetaldehyde and ethanol were measured a GC-2010 (Shimadzu Corporation, Japan), which contained a column of wax and flame ionization detector. The oven was $50^{\circ} \mathrm{C}$, the detector and injector was $127^{\circ} \mathrm{C}$ and carrier gas $\left(\mathrm{N}_{2}\right)$ flow rate $0.67 \mathrm{~mL} / \mathrm{s}$ (Park et al. 2000).

Subtracting tomato fruit weights of earliest recorded was used to measure the fresh weight loss and indicated as a percentage. Mold, decay, shriveling and similarity were considered to check the visual quality and fungal incidence on 1 - 5 (5= excellent, $4=$ very good, $3=$ acceptable, marketable, $2=$ bad and $1=$ waste) along trained five members (Islam et al. 2016). Skin color values $a^{*} / b^{*}$ of tomato fruit was assigned by a Chroma Meter of CR 400 Model (Konica Minolta Sensing, Inc., Japan). Firmness was performed by a Rheo meter (Sun Scientific Co. Ltd., Japan). Lycopene quantified with UV-Spectrophotometer (Shimadzu Corporation, Tokyo, Japan) (Fish et al.2002). Waters HPLC system was used to analyze the Vitamin C (Islam et al. 2016). Refractometer (Atago Inc., U.S.A) was performed to measure the soluble solid content. A DL 22 Food and Beverage Analyzer (Metter Toledo Ltd., Korea) used to analyze the titratable acidity and the outcome to report as a percentage of citric acid.

\section{STATISTICAL ANALYSIS}

Data were evaluated with one-way ANOVA of Duncan's multiple range tests in SPSS V. 16 (SPSS Inc., Chicago, USA).

\section{RESULTS}

Among the treatments, the $0.50 \mathrm{mM}$ sA resulted in the lowest respiration rate at harvest time as well as after storage. This result indicates that SA can prevent tomato fruit respiration, which enhances shelf life during storage. SA suppressed the ethylene production rate at harvest time and after storage and delayed ripening in treated tomato fruits (Figure 1).

SA treatments accelerated the acetaldehyde (AA) production in tomato fruits. Adding SA to the nutrient solution not only accelerated AA significantly, but also ethanol after storage. In the treatments, the $0.50 \mathrm{mM} \mathrm{SA}$ produced the highest $\mathrm{AA}$ and ethanol whereas control produced the lowest AA and ethanol (Figure 2).

A significant $(p \leq 0.05)$ lower fresh weight loss was observed in SA-treated fruit due to lower transpiration (moisture loss). Reducing the fresh weight loss of tomato fruits in storage helps maintain fruit quality. The control and $0.50 \mathrm{mM}$ treatment presented marketable visual quality ( $\geq 3$ ) for 16 and 25 days of storage, accordingly (Figure 3). The SA resulted in a reduction in fungal incidences in tomato fruit during storage (Table 1). Among the treatments, the $0.50 \mathrm{mM}$ SA treated tomato fruit had the lowest fungal incidence and the longest shelf life.

As a similar maturity stage (light red) was selected for this experiment, there were no significant differences in color, lycopene and titratable acidity at harvest time, but the tomato fruit showed significant differences in firmness, vitamin $\mathrm{C}$ and soluble solids.

The $0.50 \mathrm{mM}$ SA treatment reduced the color development, followed by the $1.00 \mathrm{mM}, 0.25 \mathrm{mM}, 0.13$ $\mathrm{mM}$ treatments and control after storage. The $0.50 \mathrm{mM}$ SA treatment slowed color development, which is helpful in prolonging shelf life (Table 1). SA-treated tomato fruit had better firmness at harvest time and after storage. SA maintained the lycopene content of tomato fruits after storage. 

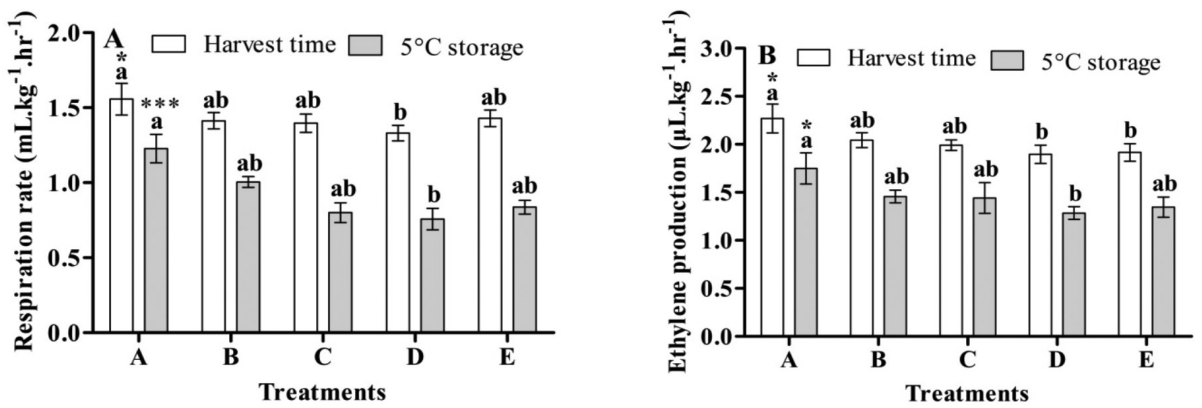

FIGURE 1. Cherry tomatoes respiration and ethylene production rate at harvest time $\left(0\right.$ day at $\left.20^{\circ} \mathrm{C}\right)$ and last storage time $\left(25^{\text {th }}\right.$ day at $5^{\circ} \mathrm{C}$ ) (A: Control, B: $0.13 \mathrm{mM}, \mathrm{C}: 0.25 \mathrm{mM}, \mathrm{D}: 0.50 \mathrm{mM}$, and E: $1.00 \mathrm{mM}$ salicylic acid). Each data point is the mean of 5 single fruit replicates \pm standard error. *, ***; significant at $p \leq 0.05$, and 0.001 of Duncan's multiple range tests (DMRT)
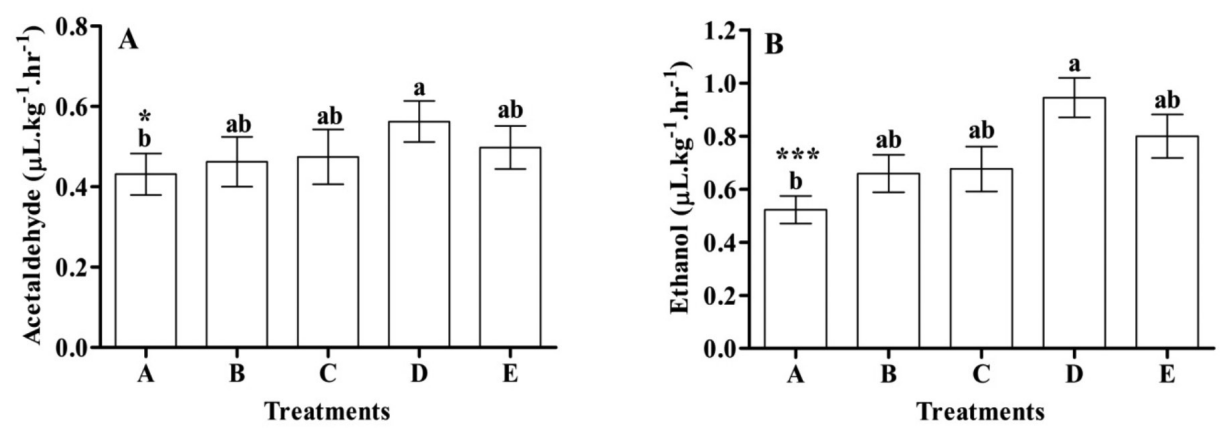

FIGURE 2 . Acetaldehyde and ethanol production rate of cherry tomatoes at harvest time $\left(0\right.$ day at $\left.20^{\circ} \mathrm{C}\right)$ and after storage time $\left(25^{\text {th }}\right.$ day at $\left.5^{\circ} \mathrm{C}\right)($ A: Control, B: $0.13 \mathrm{mM}, \mathrm{C}: 0.25 \mathrm{mM}$, D: $0.50 \mathrm{mM}$, and E: $1.00 \mathrm{mM}$ salicylic acid). Each data point is the mean of 5 single fruit replicates \pm standard error. $*, * * *$; significant at $p \leq 0.05$ and 0.001 , respectively
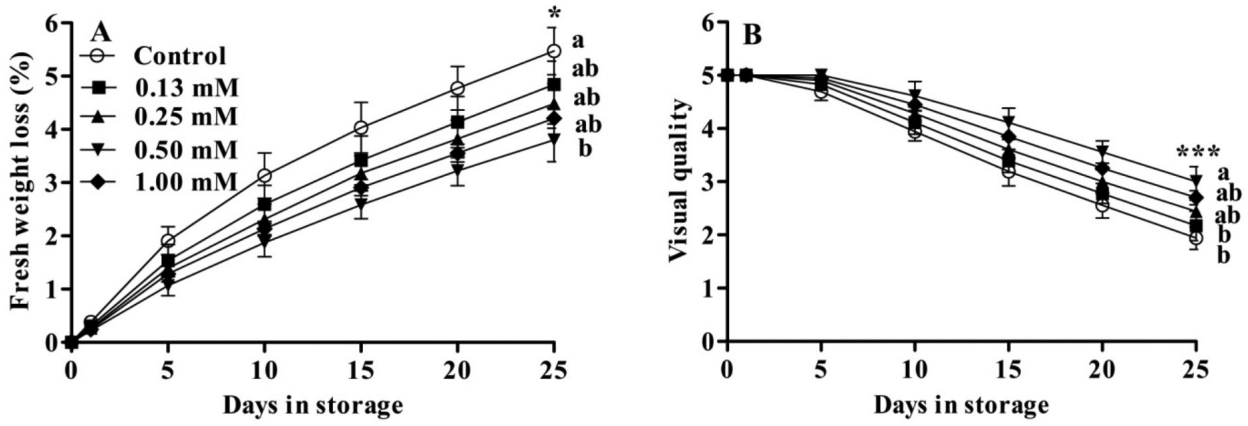

FIGURE 3. Changes of fresh weight loss (\%) and visual quality of cherry tomatoes at $5^{\circ} \mathrm{C}$ storage temperature until $25^{\text {th }}$ day. The visual quality was observed on the scale 1-5 (5: excellent, 4: very good, 3: acceptable, marketable, 2: bad and 1: waste) during at $5^{\circ} \mathrm{C}$ storage. Each data point is the mean of 10 single fruit replicates \pm standard error. ****; significant at $p \leq 0.05$ and 0.001 , respectively of Duncan's multiple range tests (DMRT)

TABLE 1 . Fungus, color, firmness and lycopene of cherry tomato at harvest time $\left(0\right.$ day at $20^{\circ} \mathrm{C}$ and after storage $\left(25^{\text {th }}\right.$ day at $\left.5^{\circ} \mathrm{C}\right)$

\begin{tabular}{lccccccc}
\hline Fungus $(\%)$ & \multicolumn{2}{c}{ Color $\left(\mathrm{a}^{*} / \mathrm{b}^{*}\right)$} & \multicolumn{2}{c}{ Firmness $(\mathrm{N})$} & \multicolumn{2}{c}{ Lycopene $(\mathrm{mg} / \mathrm{kgFW})$} \\
\hline & $5^{\circ} \mathrm{C}$ & Harvest & $5^{\circ} \mathrm{C}$ & Harvest & $5^{\circ} \mathrm{C}$ & Harvest & $5^{\circ} \mathrm{C}$ \\
\hline Control & $75.00 \mathrm{a}^{\mathrm{z}}$ & $0.72 \mathrm{a}$ & $0.82 \mathrm{a}$ & $17.37 \mathrm{~b}$ & $10.68 \mathrm{~b}$ & $99.84 \mathrm{a}$ & $159.59 \mathrm{a}$ \\
$0.13 \mathrm{mM}$ & $66.67 \mathrm{ab}$ & $0.71 \mathrm{a}$ & $0.80 \mathrm{ab}$ & $18.03 \mathrm{ab}$ & $12.55 \mathrm{ab}$ & $99.42 \mathrm{a}$ & $153.04 \mathrm{ab}$ \\
$0.25 \mathrm{mM}$ & $60.00 \mathrm{~b}$ & $0.71 \mathrm{a}$ & $0.78 \mathrm{ab}$ & $19.31 \mathrm{ab}$ & $13.62 \mathrm{ab}$ & $98.12 \mathrm{a}$ & $149.42 \mathrm{ab}$ \\
$0.50 \mathrm{mM}$ & $44.44 \mathrm{c}$ & $0.70 \mathrm{a}$ & $0.75 \mathrm{~b}$ & $20.20 \mathrm{a}$ & $15.19 \mathrm{a}$ & $99.02 \mathrm{a}$ & $139.84 \mathrm{~b}$ \\
$1.00 \mathrm{mM}$ & $49.00 \mathrm{c}$ & $0.71 \mathrm{a}$ & $0.80 \mathrm{ab}$ & $19.48 \mathrm{ab}$ & $13.98 \mathrm{ab}$ & $98.12 \mathrm{a}$ & $145.54 \mathrm{ab}$ \\
P value & $* * *$ & NS & $*$ & $*$ & $* * *$ & NS & $*$ \\
\hline
\end{tabular}

${ }^{z}$ Mean separation of columns by Duncan's multiple range tests (DMRT) ( $\left.n=10\right)$. NS, *, ***; not significant, or significant at $p \leq 0.05$, and 0.001 , respectively of Duncan's multiple range tests (DMRT) 
TABLE 2. Vitamin C, soluble solids and titratable acidity of cherry tomato at harvest time $\left(0\right.$ day at $\left.20^{\circ} \mathrm{C}\right)$ and after storage $\left(25^{\text {th }}\right.$ day at $\left.5^{\circ} \mathrm{C}\right)$

\begin{tabular}{lcccccc}
\hline & Vitamin $\mathrm{C}(\mathrm{mg} / 100 \mathrm{~g} \mathrm{FW})$ & \multicolumn{2}{c}{ Soluble solids $\left({ }^{\circ}\right.$ Brix $)$} & \multicolumn{2}{c}{ Titratable acidity $(\%$ citric acid) } \\
\hline & Harvest & $5^{\circ} \mathrm{C}$ & Harvest & $5^{\circ} \mathrm{C}$ & Harvest & $5^{\circ} \mathrm{C}$ \\
\hline Control & $16.36 \mathrm{~b}^{\mathrm{z}}$ & $10.92 \mathrm{~b}$ & $6.64 \mathrm{a}$ & $7.04 \mathrm{a}$ & $0.43 \mathrm{a}$ & $0.38 \mathrm{~b}$ \\
$0.13 \mathrm{mM}$ & $16.86 \mathrm{ab}$ & $11.3 \mathrm{~b}$ & $6.55 \mathrm{ab}$ & $6.81 \mathrm{ab}$ & $0.44 \mathrm{a}$ & $0.40 \mathrm{~b}$ \\
$0.25 \mathrm{mM}$ & $17.76 \mathrm{ab}$ & $12.61 \mathrm{ab}$ & $6.56 \mathrm{ab}$ & $6.89 \mathrm{ab}$ & $0.46 \mathrm{a}$ & $0.42 \mathrm{ab}$ \\
$0.50 \mathrm{mM}$ & $18.74 \mathrm{a}$ & $13.58 \mathrm{a}$ & $6.23 \mathrm{~b}$ & $6.61 \mathrm{~b}$ & $0.51 \mathrm{a}$ & $0.45 \mathrm{a}$ \\
$1.00 \mathrm{mM}$ & $17.96 \mathrm{ab}$ & $13.07 \mathrm{ab}$ & $6.48 \mathrm{ab}$ & $6.74 \mathrm{ab}$ & $0.45 \mathrm{a}$ & $0.41 \mathrm{ab}$ \\
P value & $*$ & $* *$ & $*$ & $*$ & NS & $*$ \\
\hline
\end{tabular}

${ }^{\mathrm{z}}$ Mean separation of columns by Duncan's multiple range tests (DMRT) $(n=10)$. NS, *, **; not significant, or significant at $p \leq 0.05$, and 0.01 , respectively of Duncan's multiple range tests (DMRT)

Tomato fruit treated with SA had higher vitamin $\mathrm{C}$ at harvest time as well as final storage day than the control. Among the treatments, the $0.50 \mathrm{mM}$ SA resulted in the highest vitamin $\mathrm{C}$ content. Comparatively lower soluble solid content resulted from the SA treatments during harvest time as well as after storage. The titratable acidity showed higher in SA treated tomato fruits at after storage (Table 2).

\section{DISCUSSION}

Reduced respiration of fruit treated with SA was observed in apples (Mo et al. 2008). Moreover, SA treatment effectively controlled fruit metabolic activity, including respiration (Babalar et al. 2007); thus, tomato fruit retained their quality and had a longer shelf life. Because respiration is a physiological process that is associated with deterioration of tomato fruit after harvest, a lower respiration rate is beneficial to long-time storage. SA delayed ripening of apples by reducing ethylene production (Mo et al. 2008). In addition, SA prevents ethylene production by decreasing 1-aminocyclopropane-1-carboxylic acid oxidase activity (Leslie \& Romani 1988), consequence of this; tomato fruits get more shelf life which is desirable to maintain fruits quality.

AA and ethanol are forerunners of natural aroma elements (Knee \& Hatfield 1981) that accumulated fruits during ripening in aerobic and anaerobic conditions and those have fungicidal and insecticidal properties and reduce ethylene production (Pesis 2005). Although there is no any report about relation between AA or ethanol and SA, the AA and ethanol produced remarkably by $0.5 \mathrm{mM}$ SA treatment may increase the resistance against pathogens in tomato fruits during storage.

SA decreased fresh weight loss by stomata closing in mandarin oranges (Zheng \& Zhang 2004) and in chrysanthemums by improving membrane permeability and decreasing lipid peroxidation (Mansouri 2012). SA treated tomato fruits showed less fresh weight loss compared with control and it may happen due to retain the moisture. SA-treated strawberry fruit showed overall excellent quality on the final storage day (Babalar et al. 2007). It is related with our experiment that tomatoes treated with SA had a longer shelf life due to SA's anti- senescent action that inhibits physicochemical and nutritional loss (Pila et al. 2010).

The SA treatment reduced fungal incidence, ethylene production and respiration in strawberries (Babalar et al. 2007). Moreover, Cai and Zheng (1999) reported that SA increased hydrogen peroxides, a signal molecule, which helps tomato plants and fruit resist pathogens. The $0.50 \mathrm{mM}$ SA treated tomato fruits showed the lowest fungal incidence and control showed the highest. The less fungal incidence in SA treatment perhaps due to hydrogen peroxides content.

Color development was reduced by the SA treatment because the ethylene production relates to ripening changes. In agreement with Mo et al. (2008), we found that SA delays the ripening process by maintaining membrane integrity and decreasing ethylene production. In apples (Mo et al. 2008) and tomatoes (Aghdam et al. 2014), SA application increases the membrane integrity and firmness. Moreover, SA increases the $\mathrm{Ca}^{2+}$ level in intercellular spaces and in plasma membranes of grape plants (Wang \& Li 2006). Our result indicated that SA treatments extend and maintain tomato firmness, which is desirable for longtime storage. SA delayed the accumulation of lycopene content in tomato fruits (Pila et al. 2010). The $0.50 \mathrm{mM}$ SA treatment resulted in less lycopene content compared with the control during tomato fruit storage due to less pigment synthesis that led to increase in the maintaining fruit quality.

The SA increased ascorbate peroxidase, which activated antioxidant abilities and vitamin $\mathrm{C}$ in peach fruit (Wang et al. 2006). The antioxidant ability of SA can prevent vitamin $\mathrm{C}$ destruction of tomato fruits during storage. Pila et al. (2010) similarly found in tomato fruits that SA retards degradation of ascorbic acid content during storage. A reduced metabolic rate has implications for better vitamin $C$ content in tomatoes (Tigist et al. 2013). In a previous study, SA-treated fruit had the lowest soluble solids because of a slowdown in the degradation of starch in apples and it reduced the separation of polysaccharides into water soluble sugar in tomatoes (Pila et al. 2010). Rohani et al. (1997) suggested that lower respiration slows down the synthesis and reduces the use of metabolites resulting in reduced soluble solids because of less conversion from carbohydrates to sugars in papayas. Perhaps the SA-treated 
tomato fruits have higher titratable acidity because of fewer metabolic changes in organic acid related to respiration after storage. This relates to Han and Li (1997) who reported higher titratable acidity after storage in apple fruit treated with SA.

\section{CONCLUSION}

Salicylic acid (SA) performance was evaluated on cherry tomato fruit quality and shelf life. The SA treatment had benefits including reduced respiration, ethylene production and fresh weight loss; delayed fungal incidence, maintained color development, lycopene content and firmness; and increased AA, ethanol, vitamin $\mathrm{C}$ and titratable acidity. The visual quality as well as shelf life influenced by the SA treatments. Applying different concentrations of SA also improved the quality and nutritional value. Furthermore, the $0.50 \mathrm{mM}$ SA treatment had the best beneficial effect of all the treatments.

\section{ACKNOWLEDGEMENTS}

This research was aided by the Export Promotion Technology Development Program (314027-3), IPET (Korea Institute of Planning \& Evaluation for Technology), Agriculture, Food and Rural Affairs Ministry, Korea.

\section{REFERENCES}

Achuo, E.A., Audenaert, K., Meziane, H. \& Hofte, M. 2004. The salicylic acid-dependent defence pathway is effective against different pathogens in tomato and tobacco. Plant Pathol. 53: 65-72.

Aghdam, M.S., Asghari, M., Khorsandi, O. \& Mohayeji, M. 2014. Alleviation of postharvest chilling injury of tomato fruit by salicylic acid treatment. J. Food Sci.Technol.51(10): 2815-2820.

Babalar, M., Asghari, M., Talaei, A. \& Khosroshahi, A. 2007. Effect of pre- and postharvest salicylic acid treatment on ethylene production, fungal decay and overall quality of Selva strawberry fruit. Food Chem. 105: 449-453.

Cai, X.Z. \& Zheng, Z. 1999. Induction of systemic resistance in tomato by and incompatible race of Cladosporium fulvum and the accumulation dynamics of salicylic acid in tomato plants. Acta. Hort. Sinica. 29: 261-264.

Enyedi, A.J., Yalpani, N., Silverman, P. \& Raskin, I. 1992. Localization, conjugation, and function of salicylic acid in tobacco during the hypersensitive reaction to tobacco mosaic virus. Proc. Natl. Acad. Sci. USA 89: 2480-2484.

Fatemi, H., Mohammadi, S. \& Aminifard, M.H. 2013. Effect of postharvest salicylic acid treatment on fungal decay and some postharvest quality factors of kiwi fruit. Arch. Phytopathology Plant Protect. 46(11): 1338-1345.

Fish, W.W., Perkins-Veazie, P. \& Collins, J.K. 2002. A quantitative assay for lycopene that utilizes reduced volumes of organic solvents. J. Food Compos. Anal. 15: 309-317.

Han, T. \& Li, L.P. 1997. Physiological effect of salicylic acid on storage of apple in short period. Plant Physiol. Comm. 33: 347-348.

Islam, M.Z., Mele, M.A., Baek, J.P. \& Kang, H.M. 2016. Cherry tomato qualities affected by foliar spraying with boron and calcium. Hortic. Environ. Biotechnol. 57(1): 46-52.
Islam, M.Z., Baek, J.P., Kim, Y.S. \& Kang, H.M. 2013. Characteristics of chilling symptoms of cherry tomato compared to beefsteak tomato harvested at different ripening stages. J. Pure Appl. Microbio. 7: 703-709.

Janda, T., Gondor, O.K. \& Yordanova, R. 2014. Salicylic acid and photosynthesis: Signaling and effects. Acta Physiol. Plant 36(10): 2537-2546.

Javanmardi, J. \& Akbari, N. 2016. Salicylic acid at different plant growth stages affects secondary metabolites and phisicochemical parameters of greenhouse tomato. Adv. Hort. Sci. 30(3): 151-157.

Kazemi, M. 2014. Effect of foliar application with salicylic acid and methyl jasmonate on growth, flowering, yield and fruit quality of tomato. Bull.Env. Pharmacol.Life. Sci.3: 154-158.

Knee, M. \& Hatfield, S.G.S. 1981. The metabolism of alcohols by apple fruit tissue. J. Sci. Food Agric. 32: 593-600.

Kumar, D., Mishra, D.S., Chakraborty, B. \& Kumar, P. 2013. Pericarp browning and quality management of litchi fruit by antioxidants and salicylic acid during ambient storage. $J$. Food Sci. Technol. 50(4): 797-802.

Leslie, C.A. \& Romani, R.J. 1988. Inhibition of ethylene biosynthesis by salicylic acid. Plant Physiol. 88: 833-837.

Mansouri, H. 2012. Salicylic acid and sodium nitroprusside improve postharvest life of chrysanthemums. Sci. Hort. 145: 29-33.

Mo, Y., Gong, D., Liang, G., Han, R., Xie, J. \& Li, W. 2008. Enhanced preservation effects of sugar apple fruits by salicylic acid treatment during post-harvest storage. J. Sci. Food Agric. 88: 2693-2699.

Park, K.W., Kang, H.M. \& Kim, C.H. 2000. Comparison of storability on film sources and storage temperature for fresh Japanese mint in MA storage. J. Bio-Environ. Control. 9(1): 40-46.

Pesis, E. 2005. The role of the anaerobic metabolites, acetaldehyde and ethanol, in fruit ripening, enhancement of fruit quality and fruit deterioration. Postharvest Biol. Technol. 37: 1-19.

Pila, N., Gol, N.B. \& Rao, T.V.R. 2010. Effect of post-harvest treatments on physicochemical characteristics and shelf life of tomato (Lycopersicon esculentum Mill.) fruits during storage. Am-Euras. J. Agric. Environ. Sci. 9: 470-479.

Rahmawati, S.L., Esyanti, R.R. \& Gunaeni, N. 2014. The role of leaf extracts as plant-activator to enhance salicylic acid production on tomato plant (Lycopersicon esculentum Mill.) infected by CMV (cucumber mosaic virus). Intl. J. Chem. Environ. Biol. Sci.2(2): 2320-4087.

Rohani, M.Y., Zaipun, M.Z. \& Norhayati, M. 1997. Effect of modified atmosphere on the storage life and quality of Eksotika papaya. J. Trop. Agric. Food Sci. 25: 103-113.

Rowshan, V. \& Bahmanzadegan,A. 2013. Effects of salicylic acid on essential oil components in Yarrow (Achillea millefolium Boiss ). Int. J. Basic Sci. Appl. Res. 2: 347-351.

Sato, S., Sakaguchi, S., Furukawa, H. \& Ikeda, H. 2006. Effects of $\mathrm{NaCl}$ application to hydroponic nutrient solution on fruit characteristics of tomato (Lycopersicon esculentum Mill.). Sci. Hort. 109: 248-253.

Spletzer, M.E. \& Enyedi, A.J. 1999. Salicylic acid induces resistance to Alternaria solani in hydroponically grown tomato. Phytopathol. 89: 722-727.

Supapvanich, S. \& Promyou, S. 2013. Effciency of salicylic acid application on postharvest perishable crops. In Salicylic Acid: Plant Growth and Development, edited by Hayat, S., Ahmad, A. \& Alyemeni, M.N. New York: Springer Science + Business Media Dordrecht Press. pp. 339-355. 
Tigist, M., Workneh, T.S. \& Woldetsadik, K. 2013. Effects of variety on the quality of tomato stored under ambient conditions. J. Food Sci. Technol. 50(3): 477-486.

Wang, L.J. \& Li, S.H. 2006. Salicylic acid-induced heat or cold tolerance in relation to $\mathrm{Ca}^{2+}$ homeostasis and antioxidant systems in young grape plants. Plant Sci. 170: 685-694.

Wang, L., Chen, S., Kong, W., Li, S. \& Archbold, D.D. 2006. Salicylic acid pre treatment alleviates chilling injury and affects the anti oxidant system and heat shock proteins of peaches during cold storage. Postharvest Biol. Technol. 41: 244-251.

Yildirim, E. \& Dursun, A. 2009. Effect of foliar salicylic acid applications on plant growth and yield of tomato under greenhouse conditions. Acta Hortic. 807(56): 395-400.

Zheng, Y. \& Zhang, Q. 2004. Effects of polyamines and salicylic acid postharvest storage of 'Ponkan' mandarin. Acta Hort. 632: $317-320$

Mohammad Zahirul Islam, Mahmuda Akter Mele \&

Ho-Min Kang

Department of Horticulture

Kangwon National University

Chuncheon 24341

Korea
Mohammad Zahirul Islam \& Ho-Min Kang*

Agriculture and Life Science Research Institute

Kangwon National University

Chuncheon 24341

Korea

Ki-Young Choi

Department of Controlled Agriculture

Kangwon National University

Chuncheon 24341

Korea

Jun Pill Baek

Department of Converged and Integrated Agro-Industry Science Catholic Sangji College

Andong 36686

Korea

*Corresponding author; email: hominkang@kangwon.ac.kr

Received: 10 August 2016

Accepted: 6 October 2017 